\title{
Enhancing primary students' understanding of social studies through the Jigsaw approach
}

\author{
Zarinah Mahari' ${ }^{1}$, Rosmawijah Jawawi², Yusimah Amjah ${ }^{3}$, Shamsinar Husain ${ }^{4}$, Nur-Ashikin Petra ${ }^{5}$, \\ Lilly Suzana Shamsu' \\ ${ }^{1}$ Sultan Ugama Arab Menengah Raja isteri Pengiran Anak Damit, Ministry of Religious Affairs, Brunei Darussalam \\ 2, 3,4, ${ }^{5}$ Sultan Hassanal Bolkiah Institute of Education, Universiti Brunei Darussalam, Brunei Darussalam \\ ${ }^{6}$ Faculty of Usuluddin, Sultan Sharif Ali Islamic University, Brunei Darussalam
}

\section{Article Info}

Article history:

Received Des 8, 2018

Revised Mar 8, 2019

Accepted May 24, 2019

\section{Keywords:}

Jigsaw approach Learning styles

Primary education

Social studies

Teaching strategies

\begin{abstract}
This study aimed to examine the implementation of the Jigsaw approach in teaching primary social studies in Brunei Darussalam. The topic selected for this study was on 'The Reign of Sultan Omar Ali Saifuddien III 1950 1967'. The sample consisted of 25 primary students in a Year 6 class. The methodology of this study was an action research. Among the instruments used were tests, observations, interviews, and students' journals. The findings showed that the students' test results had improved, indicating the effectiveness of the Jigsaw approach in teaching social studies. It was observed that there were positive developments in students' communication skills as well as their participation in the class activities. The students' motivation to learn was mostly positive as they enjoyed learning cooperatively in the given activities. However, the challenge of implementing this Jigsaw approach was the role of the teacher as a facilitator in this approach. Future research should continue to examine the different ways of teaching social studies that could involve students' active participation in the teaching and learning process.
\end{abstract}

Copyright $\odot 2019$ Institute of Advanced Engineering and Science. All rights reserved.

\section{Corresponding Author:}

Rosmawijah Jawawi,

Sultan Hassanal Bolkiah Insitute of Education,

Universiti Brunei Darussalam,

Tungku Link, BE 1310, Brunei Darussalam.

Email: rosmawijah.jawawi@ubd.edu.bn

\section{INTRODUCTION}

In realising the country's vision to produce highly skilled and productive workers, the Ministry of Education in Brunei had introduced social studies as the new curriculum subject in the primary schools. In 2009 , this subject was established in the primary curriculum to replace the subjects of Geography and History. The main objectives of social studies are to develop primary students' critical thinking as well as their knowledge and understanding of social and cultural aspects that will help to prepare them to be future active and global citizens [1]. In order to achieve these objectives effectively, teachers are expected to acquire new sets of skills in teaching and learning that emphasise on producing students, instilled with 'MIB' (translated as Malay Islamic Monarchy) values, with the 21st century skills and competencies [2-5]. Therefore, the purpose of this study was to investigate on the effectiveness of the Jigsaw approach in social studies lesson. The focus of this study was on the development of primary pupils' content knowledge in social studies. Hence, this study would attempt to answer the following research questions: How was the Jigsaw approach effective in teaching social studies lessons? What were the challenges of using the Jigsaw approach in social studies lessons?

Previous studies had reported that the use of the Jigsaw approach in teaching could be effective in enhancing students' learning [6-8]. The Jigsaw approach could be effective for aiding students' 
comprehension and students' motivation to learn (ibid). Students' achievement in learning as well as students' retention level had shown improvement during the implementation of the Jigsaw approach [9]. Majority of the students' responses were found to be positive as they found that the Jigsaw approach facilitated their understanding of the subject content [8]. However, some argued that this approach was time consuming and some students might not want to work in groups as they were used to the traditional way of learning $[7,10]$.

The main characteristic of the Jigsaw approach is for the students to complete the learning task given to their own groups [7]. In this Jigsaw approach, the students would be categorised into two groups: the original and the expert. The students would first be gathered in the original group where the teacher would assign them different tasks. Then, the students with the same task would be gathered together to form a new group called the expert group. The students would need to go back to the original group once they finish their discussion in the expert group. Once they are back to their original group, the students would then be asked to share what they have learned in the expert group with the rest of the members. Findings had shown that the students in the expert group had helped the weaker students in the group [6, 7]. Hence, the use of the Jigsaw approach in teaching had helped improved students' self-esteem and self-confidence in learning [10].

\section{RESEARCH METHOD}

The methodology used in this study was an action research. The action research was carried out in three phases: the planning phase; the action phase; and the reflection phase [11]. In this study, the first author was the teacher who taught the students by using the jigsaw approach in their social studies lesson. The social studies topic taught in this study was on 'the successful achievements of the $28^{\text {th }}$ Brunei ruler, Sultan Omar Ali Saifuddien III in developing Brunei between 1950 until 1967'. The study was conducted in three different lesson sessions. The duration of each session was 25 minutes. During the learning activities, the students were divided into groups of five. However, this study had a limited number of participants as it only involved one class that comprised of 25 primary students, aged between 11 and 12 years old, from one government primary school in Brunei. Due to the small number of the participants involved, the findings could not be generalized.

Data collected for this study were the pre- and post-test, semi-structured interviews, observation of students' participation in learning activities, students' learning activities and students' reflective journals. The pre- and post-tests were constructed to test and assessed the students' learning outcomes. Throughout this study, the ethical considerations were prioritised in this study. The students were only involved as the participants when their parents gave their consent. The identities of the school and students were kept confidential throughout the research.

\section{RESULTS AND DISCUSSION}

3.1. How was the Jigsaw approach effective in teaching social studies lessons?

\subsubsection{Development of students' content knowledge in Social Studies}

Based on the data obtained, it was found that by incorporating the Jigsaw approach in social studies lessons, the students were able to develop their conceptual understanding of the content knowledge of social studies lesson. The overall performance for all the 25 students showed improvement of their performance after the introduction of the Jigsaw approach into their social studies lessons. On average, the post-test marks reflected that the students were able to show good conceptual understanding and that their content knowledge of the lessons were much better when the Jigsaw approach was introduced to them, compared to lessons without the use of the Jigsaw approach.

Table 1 below showed the students' results for their pre- and post-tests. The table showed that there were significant improvements in the students' post-test results. Although the students were familiar with the $28^{\text {th }}$ Brunei ruler, the students' pre-test results had shown that they were not able to answer the questions in detail. Only four students passed in the pre-test (with one student scored 75 percent and others scored 50 percent) and the other students only managed to score less than 44 percent. However, after the implementation of the Jigsaw approach in social studies lessons, the students' results showed marked improvements. In the post-test, all the students passed. Student 4 and 16 with 94 percent scored the highest mark while the lowest mark was 50 percent scored by Student 18, 21, 24 and 25. 
Table 1. Comparisons between pre- and post-test marks (in percentages)

\begin{tabular}{ccc}
\hline Student Number & Pre-test $(\%)$ & Post-test $(\%)$ \\
\hline 1 & 50 & 63 \\
2 & 44 & 81 \\
3 & 44 & 63 \\
4 & 44 & 94 \\
5 & 25 & 88 \\
6 & 31 & 75 \\
7 & 38 & 88 \\
8 & 75 & 94 \\
9 & 38 & 81 \\
10 & 38 & 94 \\
11 & 38 & 94 \\
12 & 38 & 88 \\
13 & 44 & 56 \\
14 & 31 & 81 \\
15 & 38 & 88 \\
16 & 50 & 94 \\
17 & 31 & 69 \\
18 & 31 & 50 \\
19 & 31 & 81 \\
20 & 31 & 88 \\
21 & 44 & 50 \\
22 & 44 & 69 \\
23 & 31 & 69 \\
24 & 38 & 50 \\
25 & 50 & 50 \\
\hline
\end{tabular}

In the pre-test, the students struggled to provide accurate answers for their pre-test questions. Many of the students were only able to get low marks for their answers as shown in Table 1. Generally, they had difficulties in listing out the accomplishment of the $28^{\text {th }}$ Brunei ruler. The answers that the students gave were vague and lack of clarity. Hence, before the implementation of the Jigsaw approach, majority of the students were found to demonstrate a lack of understanding of social studies content. This was shown in Table 2 where the students' pre-test answers were vague and not clearly defined.

Table 2. Work sample of students' pre-test answers

\begin{tabular}{ll}
\hline Question 9. & Response \\
\hline List out the accomplishment of & Student A \\
Sultan Omar Ali Saifuddien III in & The accomplishment of Sultan Omar Ali Saifuddien III was our nation became a modern city \\
Brunei's development? & Student D \\
& The accomplishment of Sultan Omar Ali Saifuddien III was modernizing the city \\
\hline
\end{tabular}

However, after the incorporation of the Jigsaw approach into their social studies lessons, this study found that most of the students had shown great improvement in their responses to the post-test questions. Examples of students' answers during the post-test question were shown in Table 3 . The answers showed significant improvements in the students' knowledge of social studies where the students were able to remember the content learned during the Jigsaw approach. This was a contrast to the pre-test answer scripts, which reflected on their weakness in understanding of the content.

Table 3. Work sample of students' post-test answers

\begin{tabular}{ll}
\hline Question 9 & Response \\
\hline List out the accomplishment of & Student A \\
Sultan Omar Ali Saifuddien III in & Sultan Omar Ali Saifuddien built a gas plant in 1955. He set up the Brunei Teacher \\
Brunei's development? & Training Centre (BTTC) in 1956, a religious school in 1958, and the Brunei Malay \\
& Regiment in 1961. Those were the accomplishment of Sultan Omar Ali Saifuddien III. \\
& Student D \\
& He made our country became a modern Brunei. Sultan Omar Ali Saifuddien III built \\
& highways and Teacher Training Centre. He set up health and welfare services, and an army \\
& to defend our country.
\end{tabular}

\subsubsection{Improvement in students' oral communication skills}

Before the implementation of the Jigsaw approach, it was observed that the teacher had difficulties in asking the students to speak in class and to participate in any of the lesson activities. However, during the 
incorporation of the Jigsaw approach, majority of the students were observed to be discussing the answers with each other and presenting their ideas to their group members as well as to the class. Thus, the Jigsaw approach had helped to improve the students' communication skills and encourage the students to interact with each other during the lesson activities.

\subsubsection{Increase in students' motivation towards learning}

In general, it was found that majority of the students perceived the lessons as enjoyable when the teacher implemented the Jigsaw approach in their social studies lessons. During the lessons, it was observed that the students had enjoyed themselves during the activities as they showed positive participation in the group work activities. After the lessons, when the students were interviewed, most of the students said that they preferred learning activities that required them to work in teams. Majority of the students also commented that since they were comfortable with their teammates, they then felt confident in presenting their answers to the rest of the team members. Hence, the findings had shown that by incorporating the Jigsaw approach in lessons, the students were motivated to learn social studies. Figure 1 shows an excerpt of a journal entry described by one student after the Jigsaw approach lesson.

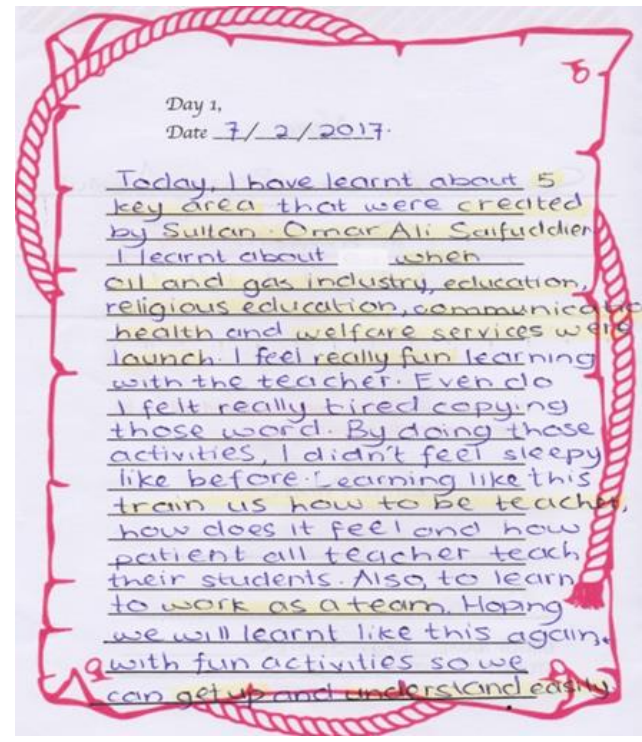

Figure 1. An excerpt of a journal entry

\subsection{Challenges of using the Jigsaw approach in social studies lessons}

Though the findings showed that the Jigsaw approach was effective in improving students' motivation to learn and their understanding of the subject matter, the change of role of the teacher from the traditional role to the facilitator could be the main challenge of implementing this approach. This finding is similar to other findings where the teacher became the facilitator in students' group activities [12-14] and [15]. Firstly, the teacher had difficulties in grouping the students. It was observed that the teacher was not familiar with the students' personalities and abilities. However, findings from other studies had shown that for any teaching approaches to be effective, students' personalities play an important role in motivating them to accomplish their tasks during learning $[8-10,16,17]$. Secondly, the teacher found the Jigsaw approach as time consuming which was similar with other findings $[7,8,10,18]$. It was observed that the application of the Jigsaw approach in social studies lesson was conducted in more than one session of the lessons. Yet, the Jigsaw approach was very effective in encouraging cooperation among the students [8]. Thirdly, the researchers found that although during the interviews, most of the students mentioned that they had enjoyed learning during the Jigsaw approach, yet some of them mentioned that they were confused. They said that the class was too noisy hence they could not hear the teacher's instructions and explanations properly, which then led to confusion. The students also added that they were not able to explain thoroughly their findings to the rest of the members in their group. Some reported that the explanations were too fast, hence caused confusions among the team members. Finally, it was found that majority of the students were not fond of their friends whom did not participate in the group work activities. This finding was similar to other findings where 'free riders' were common in students' group work activities $[2,4,10,19,20]$. 


\section{CONCLUSION}

In conclusion, the findings from this study had provided valuable insights into the use of the Jigsaw approach in the teaching of social studies for primary students. The study had highlighted the benefits as well as the challenges faced in conducting the Jigsaw approach in social studies lessons. From the research findings, the benefits were such as the improvements of the following: students' cognitive skills; students' communication skills; and students' participation in the class. These findings could be seen from the samples of the students' answers, the students' scores in the pre- and post-test, the lesson observations and the students' interview. However, there were some challenges while conducting this study such as the students' grouping, time constraint and students not participating in the learning activities.

Future research should continue to examine the different ways of teaching social studies that could involve students' active participation in the teaching and learning process. It is recommended that future study should involve a large number of participants and more topics of social studies to be included to allow a more reliable data collection. It would also be much better to examine the effectiveness of using the Jigsaw approach in secondary school students and how it can benefit other subjects apart from social studies subject.

\section{REFERENCES}

[1] Ministry of Education, The National Education System for the 21 $1^{\text {st }}$ century: SPN21, Bandar Seri Begawan: Ministry of Education, 2013.

[2] H.H. Mohammad, R. Jawawi, R. Matzin, M. Shahrill, J.H. Jaidin, L. Mundia, and L.S. Shamsu, "Engaging students' learning with elements of formative assessment," in Turkish Online Journal of Educational Technology, vol. 12, pp. 281-290, 2017.

[3] K. Wood, J.H. Jaidin, R. Jawawi, J.S.H.Q. Perera, S. Salleh, M. Shahrill, and S. Sithamparam, "How and what teachers learn from collaborative professional development," in International Journal for Lesson \& Learning Studies, vol. 6, pp. 151-168, 2017.

[4] N.D. Sulaiman, and M. Shahrill, "Engaging collaborative learning to develop students' skills of the 21st century," in Mediterranean Journal of Social Sciences, vol. 6, pp. 544-552, 2015.

[5] S. Salleh, K. Laxman, and R. Jawawi, "A Delphi Survey on Citizenship Education in ASEAN Countries: Findings for Brunei," in Journal on Educational Psychology, vol. 8, no. 4, pp. 38-52, 2015.

[6] M.J. Al-Sakhi, "The effectiveness of Jigsaw strategy on the achievement and learning motivation of the $7^{\text {th }}$ primary grade students in the Islamic education," in International Journal of Humanities and Social Science, vol 5, pp. 111-118, 2015.

[7] C.S. Kumar, S. Kalasuramath, S. Patil, K.G. Kumar, K.R. Taj, V.L. Jayasimha, K.G. Basavarajappa, P. Shashikala, A. Kukkamalla, and T. Chacko, "Effect of Jigsaw Cooperative learning method in improving cognitive skills among medical students," in International Journal of Current Microbiology and Applied Sciences, vol. 6, pp. 164-173, 2017.

[8] R.O. Zahra, "The use of Jigsaw technique in improving students' ability in writing descriptive text," in Journal of English and Education, vol. 2, pp. 64-75, 2014.

[9] H. Yapici, "Use of Jigsaw technique to teach the unit "science within time" in secondary $7^{\text {th }}$ Grade social sciences course and students' views on this technique," in Educational Research and Reviews, vol. 11, pp. 773-780, 2016.

[10] N.H. Azmin, "Effect of Jigsaw-based cooperative learning method on student performance in the General Certificate of Education Advanced-Level Psychology: An Exploratory Brunei case study," in International Education studies, vol. 9, pp. 91-106, 2016.

[11] S. Kemmis, R. McTaggart, and R. Nixon, The Action Research Planner: Doing Critical Participatory Action Research, Singapore: Springer, 2014.

[12] E. Ozdemir and A. Arslan, "The effect of self-regulated Jigsaw IV on university students' academic achievements and attitudes towards English course," in Journal of Education and Training Studies, vol. 4, pp.173-182, 2016.

[13] Q. Mengdou and J. Xiaoling, "Jigsaw strategy as a cooperative learning technique: focusing on the language learners," in Chinese Journal Applied Linguistic, vol.33, pp. 113-125, 2010.

[14] N.U.J. Yunos, R. Jawawi, R. Matzin, M. Shahrill, L. Mundia, J.H. Jaidin, N.A. Petra, and M.A. Mahadi, "Using Graphs to Develop Geographical Skills Among Pre-University Students," in Advanced Science Lettters, vol. 23, pp. 897-900, 2017.

[15] Haryono, "Learning achievement improvement efforts course learn and learning using Jigsaw method and card media in Stkip Pgri Ngawi 2014/2015 academic year," in Journal of Education and Practice, vol. 6, pp. 94-102, 2015.

[16] T. Hedeen, "The reverse Jigsaw: a process of cooperative learning and discussion," in Teaching Sociology, vol. 31, pp. 325-332, 2013.

[17] K.J. Herrman, "The impact of cooperative learning on student engagement: results from an intervention," in Active learning in higher education, vol. 14, pp. 175-187, 2013

[18] V.D. Tran and R. Lewis, "The effects of Jigsaw learning on students' attitudes in a Vietnamese higher education classroom," in International Journal of Higher Education, vol. 1, pp. 9-20, 2012.

[19] S.H. Idris, R. Jawawi, M.A. Mahadi, R. Matzin, M. Shahrill, J.H. Jaidin, N.A. Petra, and L. Mundia, "The use of rubrics in developing students' understanding of History," in Advanced Science Letters, vol. 23, pp. 901-904, 2017. 
[20] E.C. Voyles, S.F. Bailey, and A.M. Durik "New pieces of the Jigsaw classroom: Increasing accountability to reduce social loafing in student group projects," in The New School Psychology Bulletin, vol. 13, pp. 11-20, 2015.

\section{BIOGRAPHIES OF AUTHORS}

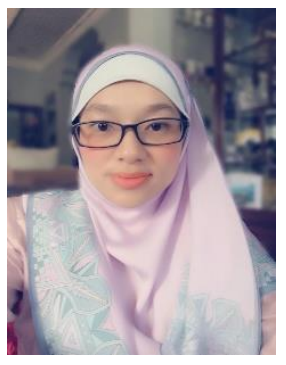

Zarinah Mahari is a primary teacher at Sultan Ugama Arab Menengah Raja isteri Pengiran Anak Damit, Ministry of Religious Affairs. She graduated with a Master degree in Teaching from the Universiti Brunei Darussalam in 2017.

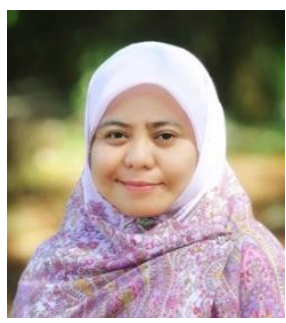

Rosmawijah Jawawi is a lecturer at Sultan Hassanal Bolkiah Institute of Education, Universiti Brunei Darussalam. She teaches and supervises Master and PhD students at the University. She specialises in pedagogy in humanities and social sciences education.

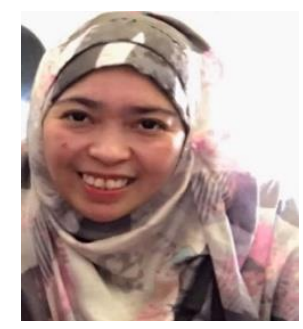

Yusimah Amjah is a lecturer at Sultan Hassanal Bolkiah Institute of Education, Universiti Brunei Darussalam. She teaches postgraduate and Master students at the University. She specializes in primary education and educational foundation.

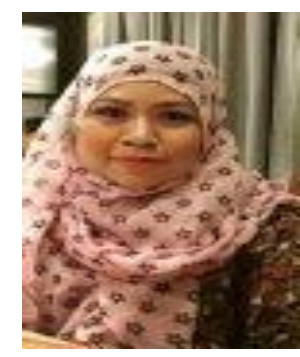

Shamsinar Husain is a lecturer at Sultan Hassanal Bolkiah Institute of Education, Universiti Brunei Darussalam. She teaches and supervises Master and PhD students at the University. She specialises in pedagogy in Arts Education.

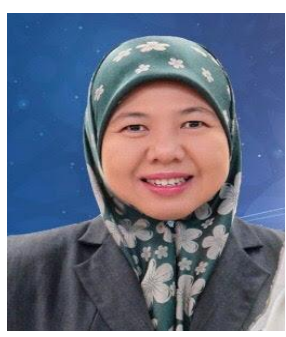

Nur-Ashikin Petra is a lecturer at Sultan Hassanal Bolkiah Institute of Education, Universiti Brunei Darussalam. She teaches and supervises Master and PhD students at the University. She specialises in Islamic knowledge education pedagogy.

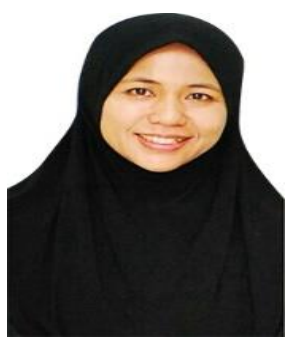

Lilly Suzana Shamsu is the Dean at the Faculty of Usuluddin, Sultan Sharif Ali Islamic Univeristy. She teaches and supervises Undergraduate, Master and PhD students at the University. Her expertise is in hadith and Islamic knowledge education. 